\title{
Investigation of Body Composition of Footballers by Bioelectrical Impedance Method
}

\author{
Yakup Aktas (Corresponding author) \\ School of Physical Education and Sports, Harran University, Sanliurfa, Turkey \\ Tel: 90-505-855-2107Ｅ-mail: yakupaktas@harran.edu.tr \\ Ismail Gokhan \\ School of Physical Education and Sports, Harran University, Sanliurfa, Turkey \\ Tel: 90-544-604-6369 E-mail: is_gokhan@hotmail.com
}

Received: August 19, 2019 Accepted: September 19, 2019

Published: September 24, 2019

doi:10.5296/jei.v5i2.15300 URL: https://doi.org/10.5296/jei.v5i2.15300

\begin{abstract}
Objective: This study aims at examining the body composition of male football players who perform regular football training by Bioelectrical Impedance (BIA) method and comparing it with a healthy control group and investigating the effect of regular exercise on body composition.
\end{abstract}

Materials and Methods: A total of 60 people participated in the study, including 30 volunteer male football players performing football trainings regularly from 11 Nisan Football Club playing in Turkey Football Federation Regional Amateur League (BAL) and 30 healthy volunteer control group consisting of male students from Harran University Medical Faculty. Both groups' ages and body mass indexes are similar to each other. Bioelectrical Impedance (BIA) method was used for Osseosis, skeletal muscle weight (SMM), body mass index (BMI), body fat percentage (BFP), waist hip ratio (WHR), and basal metabolism parameters of the participants. The data obtained were evaluated with SPSS 23.0 statistical package program, and the significance level was evaluated as $\mathrm{p}<0.01$ and $\mathrm{p}<0.05$.

Findings: There was no statistically significant difference between the values of age, height, weight, intracellular fluid, extracellular fluid, protein, mineral, skeletal muscle weight (SMM), body mass index (BMI) and muscle ratios of the experimental and control groups $(p>0.05)$. When the parameters of basal metabolism, Osseosis and skeletal muscle weight of the 
experimental group were discussed, no significant relationship was detected, although they were high numerically $(p>0.05)$. It was determined that the body fat percentage (BFP) of the experimental and control groups was correlated at $\mathrm{p}<0.01$ level and waist-hip ratio was correlated (WHR) at $\mathrm{p}<0.05$ level, which was statistically significant. As a result, although there was no significant difference between BMI values between the football players and the control group, the fact that the players' lower BMI values and lower waist-hip ratios showed that regular training reduces the risk of developing chronic diseases.

Keywords: Football, Bioelectrical impedance, Body composition

\section{Introduction}

In recent years, the physical inactivity caused by industrialization and sedentary lifestyle adversely affects individuals in every age group. A sedentary lifestyle brings serious health problems together with it (Çolakoğlu \& Şenel, 2003). This sedentary lifestyle is a serious public health problem that occurs as a result of energy imbalance and decreases the quality of life and duration due to the fact that the energy consumed is less than the energy received (Şanlier, 2005; Şanl1, 2008). Body mass index and body fat ratio measurements are among the most frequently used methods to gather information about the health status of individuals in medical fields, such as obesity and cardiology, sports science studies, and the fields related to public health (Dal Cin, Braga, Molinari, Cristallo, \& Di Carlo, 1992; Erselcan, Candan, Saruhan, \& Ayca 2000). Body mass index $\left(B M I \mathrm{~kg} / \mathrm{m}^{2}\right)$ is calculated for body weight assessment in sedentary individuals, and BMI classification determined by the World Health Organization (WHO, 2016) is examined. However, when BMI evaluation is carried out, the person can be evaluated as overweight because the muscular and bone mass of the individuals participating in sports is higher compared to sedentary individuals. Therefore, it is more accurate to evaluate body composition, especially body fat ratio in athletes (Şakar, 2010). Since abdominal lipoidosis is a greater risk factor for cardiovascular disease than peripheral lipoidosis, evaluation of regional lipoidosis is of great importance (Björntorp, 1997). Waist/hip ratio and waist circumference measurement is also important for the evaluation of abdominal obesity (Lean, Han, \& Morrison 1995). There are different methods used to detect regional lipoidosis and to determine body composition. Of these, the bioelectrical impedance method is one of the most common because it tests body analysis accurately, quickly, and easily, and it tests many parameters together. Bioelectrical impedance method (BIA) has been seen as a suitable method for the determination of body composition and clinical epidemiological studies in recent years (Kaya \& Özçelik, 2009). Bioelectrical impedance is based on the principle of determining the body composition by giving current to the body at low levels and at different frequencies (Canpolat, 2018).

A footballer is expected to have certain morphological and physiological attributes in order to make a continuous and successful career. A significant correlation between body mass, muscle mass and work-rate profile has been established (Rienzi, Drust, Reilly, Carter, \& Martin, 2000). Body mass can affect the speed, durability and physical dominance of athletes, while the composition of the body inevitably affects the strength and agility, and for the successful of football individual requires a high level of athletic abilities and appropriate 
atropometric characteristics and body composition, beside high level of technical and tactical skills (Popovic, Akpinar, Jaksic, Matic, \& Bjelica, 2013).

There is abundant research available regarding the performance relationship of body composition, including football and many other branches (Mangine, Noyes, Mullen, \& Barber-Westin, 1990; Ostojic, 2002). This study aims to examine the body composition of male football players who perform regular football training with Bioelectrical Impedance (BIA) method, and compare it with a healthy control group to investigate the effect of regular exercise on body composition.

\section{Method}

A total of 60 people participated in the study, including 30 male football players (experimental group) from Şanliurfa 11 Nisan Football Club playing in Turkey Football Federation Regional Amateur League (BAL) performing football trainings regularly as five days a week, two hours a day, who have played sports for nine years. The control group consisted of 30 healthy male student volunteers from Harran University Medical Faculty, whose ages and body mass indexes are similar to the experimental group, and are not performing football trainings regularly. The age, height, and weight of the participants are shown in Table 1.

Table 1. The mean age, height and body weights of the groups and their statistical comparison

\begin{tabular}{|l|l|l|}
\hline Parameters & $\begin{array}{l}\text { Experimental Group }(\boldsymbol{n}=\mathbf{3 0}) \\
\mathbf{X} \pm \mathbf{S s}\end{array}$ & $\begin{array}{l}\text { Control Group }(\boldsymbol{n}=\mathbf{3 0}) \\
\mathbf{X} \pm \mathbf{S s}\end{array}$ \\
\hline Year (year) & $21.66 \pm 2.74$ & $21.23 \pm 1.19$ \\
\hline Height (cm) & $1.77 \pm 0.06$ & $1.76 \pm 0.005$ \\
\hline Weight (kg) & $70.04 \pm 7.66$ & $72.61 \pm 11.38$ \\
\hline
\end{tabular}

\subsection{Data Collection}

\subsubsection{Measurements of Height and Body Weight}

The height of the participants was measured using a wall-mounted stadiometer (Holtain Ltd., UK) with a precision of $\pm 1 \mathrm{~mm}$. Height measurements were taken with bare feet and with arms hanging freely from shoulders to sides. The measurements were taken with the head upright, the feet flatly stepped on the floor, the knees stretched, the heels adjacent, and the body upright. Body weights were measured with a BIA device with a precision of 0.1 with bare feet and minimal clothing.

\subsubsection{Body Analysis}

Body compositions, body weight, protein, mineral, BMI, right arm, left arm, right leg, left leg, right leg circumference and left leg circumference, basal metabolism, Osseosis, SMM, VYY 
and WHR parameters of the participants were determined by Bioelectrical Impedance (In Body 720) method by printing out automatically. The participants were informed in advance about the rules to be considered in BIA measurement and they were asked not to participate in sports or drink alcohol in the 24 hours before the test, as well as not to consume food and drinks 3-4 hours before the test day. Participants were asked to stand on bare feet on the metal surface of the device, to hold the hand-held parts of the device with both hands, and to release their arms parallel to the body.

\subsection{Data Analysis}

Independent samples-t test analysis was used to compare the experimental and control groups. The data obtained were evaluated with SPSS 23.0 statistical package program, and the significance level was evaluated as $\mathrm{p}<0.01$ and $\mathrm{p}<0.05$.

\section{Results}

Table 2 shows the data of comparison of the body analyses of the experimental and control groups at the end of this study to examine the body composition of the football players who perform regular football training and the control group who do not train regularly.

Table 2. Bioelectrical impedance means and comparison results of groups

\begin{tabular}{|l|l|l|l|}
\hline Parameters & $\begin{array}{l}\text { Experimental Group }(\boldsymbol{n}=\mathbf{3 0}) \\
\mathbf{X} \pm \mathbf{S}\end{array}$ & $\begin{array}{l}\text { Control Group (n= 30) } \\
\mathbf{X} \pm \mathbf{S}\end{array}$ & $\boldsymbol{p}$ \\
\hline Protein & $12.68 \pm 1.38$ & $12.04 \pm 1.52$ & 0.117 \\
\hline Mineral & $4.22 \pm 0.51$ & $4.06 \pm 0.58$ & 0.313 \\
\hline Osseosis & $3.46 \pm 0.42$ & $3.33 \pm 0.49$ & 0.338 \\
\hline SMM (kg) & $36.13 \pm 4.27$ & $34.36 \pm 4.61$ & 0.153 \\
\hline VKI (kg/height $\left.{ }^{2}\right)$ & $22.26 \pm 1.45$ & $23.19 \pm 3.06$ & 0.179 \\
\hline VYY \% & $9.75 \pm 3.97$ & $16.11 \pm 6.21$ & $\mathbf{0 . 0 0 0}$ \\
\hline WHR & $0.83 \pm 0.02$ & $0.86 \pm 0.04$ & $\mathbf{0 . 0 1 1}$ \\
\hline Right arm (kg) & $3.53 \pm 0.56$ & $3.38 \pm 0.56$ & 0.328 \\
\hline Left arm (kg) & $3.47 \pm 0.53$ & $3.34 \pm 0.54$ & 0.412 \\
\hline Right Leg (kg) & $10.09 \pm 1.15$ & $9.61 \pm 1.08$ & 0.120 \\
\hline Left Leg (kg) & $9.99 \pm 1.17$ & $9.51 \pm 1.15$ & 0.141 \\
\hline Right Leg circumference (cm) & $52.37 \pm 2.60$ & $52.81 \pm 4.01$ & 0.648 \\
\hline Left Leg circumference (cm) & $50.60 \pm 8.40$ & $52.52 \pm 3.95$ & 0.273 \\
\hline Basal Metabolism & $1733.12 \pm 150$ & $1676.03 \pm 168$ & 0.201 \\
\hline Note p $<0.01,0<05$ & &
\end{tabular}

Note. ${ }^{* *} \mathrm{p}<0.01, \stackrel{*}{\mathrm{p}}<0.05$. 
When Table 2 is examined, we can see in the body composition values of the experimental and control groups that protein was $12.68 \pm 1.38,12.04 \pm 1.52$; mineral was $4.22 \pm 0.51$, $4.06 \pm 0.58$; osseosis was $3.46 \pm 0.42,3.33 \pm 0.49$; SMM was $36.13 \pm 4.27,34.36 \pm 4.61$ and basal metabolism was $1733.12 \pm 150,1676.03 \pm 168$. From these parameters, we can conclude that parameters were found to be higher in favour of the experimental group; no significant relationship was detected between the groups $(\mathrm{p}>0.05)$. When the BMI values of the experimental and control groups were examined, it was 22.26 $\pm 1.45,23.19 \pm 3.06$, and although it was numerically low in favour of the experimental group, no significant relationship was found between the groups $(p>0.05)$.

The body fat percentage (BFP) of the experimental and control group was 9.75 \pm 3.97 , $16.11 \pm 6.21(\mathrm{p}<0.01)$ level respectively, and waist-hip ratio (WHR) was $0.83 \pm 0.02,0.86 \pm 0.04$ $(\mathrm{p}<0.05)$ levels respectively, which was statistically significant.

\section{Discussion}

In our study, the mean age of the players was $21.66 \pm 2.74$, the mean height was $1.77 \pm 0.06$, and the mean body weight was $70.04 \pm 7.66$. When we check the studies investigating the physical and motoric features of football players playing in the league, we can see that they show in approximate value with age, height and body weight averages in our study (Aslan \& Ersöz, 2012; Bunc, Hrasky, \& Skalska, 2015; Cossio-Bolanos, Portella, Hespanhol, Fraser, \& Arruda, 2012; Gerosa-Neto, Rossi, Silva, Zapeterra, Fernandes, \& Junior, 2014; Kashani, Khotbesara, Maskooni, \& Djafarian, 2013; Zagatto, Miyagi, Brisola, Milioni, Silva, Santiago, \& Papoti 2015).

In their studies on football players and students from Nigde University who do not participate in regular sports by the skinfold method, Eker, Ağaoğlu, and Albay (2003) measured body fat percentages and stated that body fat percentages were significantly less. In their studies on students of Cumhuriyet University School of Physical Education and Sports and elite level athletes group consisting of active athletes, Sirtakavak et al. (2004) found that body fat percentages were $11.80 \%$. Using BIA method, Karakaş, Taşer, Yıldız, and Köse (2005) measured body fat percentages of students at a school of physical education and medical school students and found that body fat percentages of students were $12.95 \%$, and body fat percentages of medical school students were $15.40 \%$, and they stated that the difference was statistically significant. In their studies examining the relationship between physical and motoric properties and technical capacities of players playing in the BAL league, Aslan and Ersöz (2012) determined that the average body fat ratio of the players was 7.70. Similarly, it has been determined that different activities involved in physical activity and applied for a certain period cause a decrease in body fat percentages of individuals (Gökdemir, Koç, \& Yüksel, 2007; Orhan, Pulur, \& Erol, 2008; Toraman, Yaman, Şahin, Ayçem, \& Muratl1, 2002; Yüksel, Koç, Özdilek, \& Gökdemir, 2007).

When the studies on footballers in different countries are examined, Cossio Bolanos et al. (2012) found that body fat ratio of Peruvian football players was $11.4 \pm 2.9 \%$. In their study on Iranian football players, Kashani et al. (2013) found that body fat ratio of football players was $10.1 \pm 3.5 \%$. In their studies on Brazilian football players, Gerosa-Neto et al. (2014), found 
that body fat ratio was $14 \pm 5.2 \%$. In their studies on Italian football players, Zagatto et al. (2015) found that body fat ratio of football players was $11.8 \pm 1 \%$. In their studies on Czech football players, Bunc et al. (2015) found that body fat ratio of football players was $10.4 \pm 1.7 \%$. The mean body fat ratio of the players participating in this study was $9.75 \pm 3.97$, which is similar to the existing literature. The mean body fat ratio of the players and the control group was found to be statistically significant $(\mathrm{p}<0.01)$, and it is similar to the aforementioned studies. As the percentage of body fat increases, the risk of developing chronic diseases increases. As is evidenced by the aforementioned studies, at the end of these studies, exercise and active life have positive effects on decreasing body fat percentage. In their studies examining the relationship between the physical and motoric characteristics and technical capacities of the players playing in the BAL league, Aslan and Ersöz (2012) determined that body mass index $\left(\mathrm{kg} / \mathrm{m}^{2}\right)$ of the football players was $22.9 \pm 2.9$. In their study on Iranian players, Kashani et al. (2013) found that the average BMI was $23.2 \pm 1.4 \mathrm{~kg} / \mathrm{m}^{2}$.

When previous studies are analysed, some studies show that there is a positive relationship between BMI and regular exercise (Bilim, Çetinkaya, \& Dayı, 2016; Sarıta, Yıldı, \& Hayta, 2017; Saygın, Polat, \& Karacabey, 2005). In addition, there are some studies showing that regular exercise has no effect on BMI (Kurt et al., 2010; Poyraz et al., 2015; Selçuk \& Karacan, 2017). Moreover, Bielec et al. (2013) reported that there was no significant difference between the body mass indexes of the swimmers they followed for two years and the control group. In another study, Sideraviciute et al. (2006) found that, although swimming exercise performed for 14 weeks and two days a week caused a decrease in body fat tissue in girls aged 14-19, there was no change in BMI.

It is expected that athletes have lower body weights with exercise. However, it is also expected that BMI will increase due to the fact that regular exercise increases muscle mass in the body. The mean BMI of the players participating in the current study was $22.26 \pm 1.45$ $\mathrm{kg} / \mathrm{m} 2$, which is in parallel with the existing literature. When the relationship between the mean BMI of the experimental and control groups in the study was examined, it was found that the skeletal muscle weights of the experimental group were higher, body fat ratio was lower, and the control group had no statistically significant relationship due to the excess of the body fat ratio. Çelik and Toksöz (1999) found that the average waist-hip ratio of male students studying at Dicle University physical education and sports department was $0.80 \pm 0.03 \mathrm{~cm}$. Özder et al. (2003), in their study on 21 male footballers of Gençlerbirliği sports club, found that the average waist-hip ratio of the players was $0.90 \pm 0.01 \mathrm{~cm}$. In the current study, the average waist-hip ratio of the players was $0.83 \pm 0.02 \mathrm{~cm}$, and the average waist-hip ratio of the control group was $0.86 \pm 0.04 \mathrm{~cm}$. In addition, it was seen that there was a statistically significant relationship between the waist-hip ratios of the football players and control group $(\mathrm{p}<0.05)$.

As a result, previous research shows that increasing body fat percentage and waist-hip ratio increases the risk of cardiovascular diseases and triggers other chronic diseases. Although there was no significant difference between BMI values between the players and the control group, lower body fat percentage values and lower waist-hip ratios of the players showed that regular training reduced the risk of developing chronic diseases. In addition, as a result of the 
data obtained from the study, it is thought that bioelectrical impedance method will be useful in the evaluation of body composition and body mass index, body fat percentage, and waist-hip ratio among disease risk factors.

\section{Acknowledgements}

This study was supported by Harran University Scientific Research Projects (BAP) unit with the project number 18032 dated 19-03-2018. Prior to the study, approval of compliance with ethical rules was taken by Harran University Rectorate Health Sciences Ethics Committee with the decision dated 16.11.2018 and numbered 2011.5.1/2.

\section{References}

Aslan, C. S., \& Ersöz, G. (2012). Futbolcuların seçilmiş fiziksel ve motorik özellikleri ile teknik kapasiteleri arasındaki ilişkinin incelenmesi. Spor Hekimliği Dergisi Cilt, 47, 89-96.

Bale, P. (1980). The relationship of physique and body composition to strength in a group of physical education students. Br J Sports Med, 14(4), 19398. https://doi.org/10.1136/ bjsm.14.4.193

Bilim, A. S., Çetinkaya, C., \& Dayı, A. (2016). 12-17 Yaş arası spor yapan ve spor yapmayan öğrencilerin fiziksel uygunluklarının incelenmesi. Spor ve Performans Araştırmaları Dergisi, 7(2), 53-60. https://doi.org/10.17155/spd.74209

Björntorp, P. (1997). Body fat distribution, insulin resistance, and metabolic diseases. Nutrition, 13, 795-803. https://doi.org/10.1016/S0899-9007(97)00191-3

Bunc, V., Hrasky, P., \& Skalska, M. (2015). Changes in body composition, during the season, in highly trained soccer players. Sports Sciences Journal, 8(1), 18-24. https://doi.org/ $10.2174 / 1875399 X 01508010018$

Canpolat, E. (2018). Biyoelektrik impedans analizi parametrelerinden faz açısının, tanısal kriter olarak olası rolü. İnönü Üniversitesi Să̆lık Bilimleri Dergisi, 7(1), 58-65.

Çelik, F., \& Toksöz, P. (1999). Dicle Üniversitesi Beden Eğitimi ve Spor Bölümünde Okuyan Öğrencilerin Besin Tüketim Düzeyleri ve Beslenme Alışkanlıkları. Beslenme Ve Diyet Dergisi, 28(1), 4-9.

Çolakoğlu, F. F., \& Şenel, Ö. (2003). Sekiz haftalık aerobik egzersiz programının sedanter orta yaşlı bayanların vücut kompozisyonu ve kan lipidleri üzerindeki etkileri. Spormetre, Ankara Üniversitesi Beden Eğitimi ve Spor Bilimleri Dergisi, 1, 56-61. https://doi.org/ 10.1501/Sporm_0000000007

Cossio-Bolanos, M., Portella, D., Hespanhol, J. E., Fraser, N., \& Arruda, M. (2012). Body size and composition of the elite peruvian. Journal oaf Exercise Physiology, 15(3), 30-38.

Dal Cin, S., Braga, M., Molinari, M., Cristallo, M., \& Di Carlo, V. (1992). Role of bioelectrical impedance analysis in acutely dehydrated subjects. Clinical Nutrition, 11(3), 128-133. https://doi.org/10.1016/0261-5614(92)90072-X 
Eker, H., Ağaoğlu, Y. S., \& Albay, F. (2003). Niğde Üniversitesindeki 20-25 yaş arası futbol oynayan, futbolu bırakan ve düzenli spor yapmayan öğrencilerin solunum ve antropometrik parametrelerinin incelenmesi. Spormetre Beden Eğitimi ve Spor Bilimleri Dergisi, 1, 89-97. https://doi.org/10.1501/Sporm_0000000135

Erselcan, T., Candan, F., Saruhan, S., \& Ayca, T. (2000). Comparison of body composition analysis methods in clinical routine. Annals of Nutrition and Metabolism, 44(5-6), 243-248. https://doi.org/10.1159/000046691

Gerosa-Neto, J., Rossi, F. E., Silva, C. B., Zapeterra, C., Fernandes, R. A., \& Junior, I. F. (2014). Body composition analysis of athletes from the elite of brazilian soccer players. Motricidade, 10(4), 105-110. https://doi.org/10.6063/motricidade.10(4).3567

Gökdemir, K., Koç, H., \& Yüksel, O. (2007). Aerobik antrenman programının üniversite öğrencilerinin bazı solunum ve dolaşım parametreleri ile vücut yă̆ oranı üzerine etkisi. Egzersiz, 1, 44-49.

Karakaş, S., Taşer, F., Yıldız, Y., \& Köse, H. (2005). Tıp Fakültesi ve Spor Yüksekokulu Öğrencilerinde biyoelektriksel impedans analiz (bia) yöntemi ile vücut kompozisyonlarının karşılaştırılması. ADÜ Tıp Fakültesi Dergisi, 6, 5-9.

Kashani, A., Khotbesara, R. D., Maskooni, M. D., \& Djafarian, K. (2013). Body composition of elite iranian soccer players. International Research Journal of Applied and Basic Sciences, 7(14), 1184-1188.

Kaya, H., \& Özçelik, O. (2009). Vücut bileşimlerinin değerlendirilmesinde vücut kitle indeksi ve biyoelektrik impedans analiz metodlarının etkinliğinin yaş ve cinsiyete göre karşılaştırılması. FÜ Să̆ Bil Tip Derg, 23, 1-5.

Kurt, S., Hazar, S., İbiş, S., Albay, B., \& Kurt, Y. (2010). Orta yaş sedanter kadınlarda sekiz haftalık step-aerobik egzersizinin bazı fiziksel uygunluk parametrelerine etkilerinin değerlendirilmesi. Uluslararası İnsan Bilimleri Dergisi, 7(1), 666-674.

Lean, M. E. J., Han, T. S., \& Morrison C. E. (1995). Waist circumference as a measure for indicating need for weight management. $B M J, 311,158-61$. https://doi.org/10.1136/bmj.311. 6998.158

Mangine, R. E., Noyes, F. R., Mullen, M. P., \& Barber-Westin, S. D. (1990). A physiological profile of the elite soccer athlete. J Orthop Sports Physther, 12(4), 147-52. https://doi.org/ 10.2519/jospt.1990.12.4.147

Orhan, S., Pulur, A., \& Erol, A. E. (2008). İp ve ağırlıklı ip çalışmalarının basketbolcularda bazı fiziksel ve fizyolojik parametrelere etkisi. F.Ü. Să̆lık Bilimleri Tıp Dergisi, 22, 205-210.

Ostojic, S. M. (2002). Changes in body fat content of top-level soccer players. Journal of Sports Science and Medicine, 1, 54-55.

Özder, A., Gültekin, T., Koca, B., \& Akın, B. (2003). Elit erkek sporcularda vücut oranlarının karşılaştırılması. SPORMETRE Beden Eğitimi ve Spor Bilimleri Dergisi, 1(1), 63-67. 
https://doi.org/10.1501/Sporm_0000000005

Popovic, S., Akpinar, S., Jaksic, D., Matic, R., \& Bjelica, D. (2013). Comparative Study of Anthropometric Measurement and Body Composition between Elite Soccer and Basketball Players. International Journal of Morphology, 31(2), 461-7. https://doi.org/10.4067/ S0717-95022013000200016

Poyraz, A., Baş, O., Ocak, Y., Yıldırım, İ., \& Tortop, Y. (2015). Avrupa badminton takım şampiyonası'na katılan sporcuların bazı fiziksel ve fizyolojik özelliklerinin karşılaştırılması. Spor ve Performans Araştırmaları Dergisi, 6(2), 121-133. https://doi.org/10.17155/spd.56155

Rienzi, E., Drust, B., Reilly, T., Carter, J. E. L., \& Martin, A. (2000). Investigation of The Anthropometric and Work Rate Profiles of Elite South American Soccer Players. J Sports Med Phys Fitness, 40, 162-169.

Şakar, Ş. (2010). Sporcularda Sağlık1 Beslenme. Türkiye Klinikleri, 3(2), 42-52.

Şanl1, E. (2008). Öğretmenlerde fiziksel aktivite düzeyi-yaş, cinsiyet ve beden kitle indeksi ilişkisi (Yüksek Lisans Tezi, Gazi Üniversitesi Sağlık Bilimleri Enstitüsü, Ankara).

Şanlıer, N. (2005). Gençlerde biyokimyasal bulgular, antropometrik ölçümler, vücut bileşimi, beslenme ve fiziksel aktivite durumlarının değerlendirilmesi. Gazi Eğitim Fakültesi Dergisi, $25,47-73$.

Sarıtaş, N., Yıldız, K., \& Hayta, Ü. (2017). İlkokul öğrencilerinin bazı motorik ve fizyolojik özelliklerinin karşılaştırılması. CBÜ Beden Ĕ̆itimi ve Spor Bilimleri Dergisi, 12(2), 117-127.

Saygın, Ö., Polat, Y., \& Karacabey, K. (2005). Çocuklarda hareket eğitiminin fiziksel uygunluk ve özelliklerine etkisi. Fırat Üniversitesi Sağllk Bilimleri Dergisi, 19(3), 205-212.

Selçuk, H., \& Karacan, S. (2017). 11-13 Yaş grubu erkek yüzme sporcularında 12 haftalık terabant antrenmanının yüzme performansına etkileri. Journal of Human Sciences, 14(4), 4958-4968. https://doi.org/10.14687/jhs.v14i4.4858

Sideraviciūte, S., Gailiūniene, A., Visagurskiene, K., \& Vizbaraite, D. (2006). The effect of long-term swimming program on body composition, aerobic capacity and blood lipids in 14-19-year aged healthy girls and girls with type 1 diabetes mellitus. Medicina (Kaunas), 42(8), 661-666.

Sınırkavak, G., Dal, U., \& Çetinkaya, Ö. (2004). Elit sporcularda vücut kompozisyonu ile maksimal oksijen kapasitesi arasındaki ilişki. C. Ü. Tıp Fakültesi Dergisi, 26, 171-176.

Spor ve Performans Araştırmaları Dergisi, 6(2), 121-133.

Toraman, F., Yaman, H., Şahin, G., Ayçem, N., \& Muratlı, S. (2002). 9 Haftalık bir antrenman programının yaşlıların beden bileşimleri üzerine etkisi. Turk J. Geriatr, 5, 91-96.

WHO (World Health Organization). (2016). Retrieved from http://apps.who.int/bmi/index.jsp

Yüksel, O., Koç, H., Özdilek, Ç., \& Gökdemir, K. (2007). Sürekli ve interval antrenman programlarının üniversite öğrencilerinin aerobik ve anaerobik gücüne etkisi. Sağllk Bilimleri 
Dergisi, 16, 133-139.

Zagatto, A. M., Miyagi, W. E., Brisola, G. M., Milioni, F., Silva, A. S., Santiago, P. R., \& Papoti, M. (2015). Correlation between hoff test performance, body composition. Sport Sciences for Health, 11(1), 73-79. https://doi.org/10.1007/s11332-014-0210-0

\section{Copyright Disclaimer}

Copyright for this article is retained by the author(s), with first publication rights granted to the journal.

This is an open-access article distributed under the terms and conditions of the Creative Commons Attribution license (http://creativecommons.org/licenses/by/3.0/). 